\title{
Morphological characteristics and soybean yields after using different limestone
}

\author{
Adaniel Sousa dos Santos ${ }^{1}$, Leandro Pereira Pacheco ${ }^{2}$, Rafael Felippe Ratke ${ }^{3}$, Weverson Lima Fonseca ${ }^{1}$, Alan \\ Mario Zuffo ${ }^{3^{*}}$, Francisco de Alcântara Neto ${ }^{4}$, Júlio César Azevedo Nóbrega ${ }^{5}$, João Batista da Silva Oliveira ${ }^{1}$, \\ Tiago de Oliveira Sousa ${ }^{1}$, Aline Sousa dos Santos ${ }^{1}$
}

\author{
'Federal University of Piauí, 64900-000, Bom Jesus, Piauí, Brazil \\ ${ }^{2}$ Federal University of Rondonópolis, 78735-901, Rondonópolis, Mato Grosso, Brazil \\ ${ }^{3}$ Federal University of Mato Grosso do Sul, 79560-000, Chapadão do Sul, Mato Grosso do Sul, Brazil \\ ${ }^{4}$ Federal University of Piauí, 64049550, Teresina, Piauí, Brazil \\ ${ }^{5}$ Federal University of Recôncavo da Bahia, 44380-000, Cruz das Almas, Bahia, Brazil
}

*Corresponding author: alan_zuffo@hotmail.com

\begin{abstract}
In this study, the growth and productive characteristics of the soybean were investigated in no-till system after using limestone in a tropical soil of the Brazilian Cerrado. The study was conducted in a Typic Hapludox. The sources of limestone came from Piauí miners (C1, C2 and C3) and from a mining company in Ceará (C4) plus a control treatment (without limestone), with four replicates, during the 2013/2014 and 2014/2015 growing seasons, in a randomized block design. The limestone was applied in October 2012, using a gravity distribution. The limestone rate applied was $2.73 \mathrm{Mg} \mathrm{ha}^{-1}$ to raise the soil base saturation to $60 \%$. The final plant stand, relative chlorophyll index, leaf area index, shoot dry matter, photosynthetically active radiation, the efficiency of photosynthetically active radiation, number of stems, pod number per plant, thousand-grain mass and grain yield of the soybean were evaluated. There were significant differences between the sources of limestone, with emphasis on the sources C1 and C4 due to the greater increases in plant growth and soybean grain yield ( $79 \%$ and $90 \%$, respectively, in the 2014/2015 harvest). Soybean yield is correlated to the vegetative and reproductive development of the plant when cultivated in a tropical soil of the Cerrado corrected with limestone.
\end{abstract}

Keywords: Oxisol; No-till; Glycine max; Pearson correlation network.

Abbreviations: RTNP_relative total neutralization power; $\mathrm{SO}_{2}$ sulfur dioxide; $\mathrm{NH}_{3}$ ammonia; $\mathrm{HNO}_{3}$ nitric and hydrochloric acid.

Introduction

Low soil pH limits the availability of most mineral nutrients in the soil to the plant and may intensify the release of metal ions such as $\mathrm{Cu}^{2+}, \mathrm{Fe}^{2+}, \mathrm{Mn}^{2+}, \mathrm{Zn}^{2+}$, and $\mathrm{Al}^{3+}$. These metal ions in high availability in the acid soils may become phytotoxic to plants (Caires et al., 2008). The $\mathrm{Al}^{3+}$ at phytotoxic levels limits plant growth and development, and results in the displacement of basic cations such as $\mathrm{Ca}^{2+}$ and $\mathrm{Mg}^{2+}$ from the exchange complex, reducing the availability of these essential nutrients to plants (Martins et al.. 2016). The hydrolysis of exchangeable $\mathrm{Al}^{3+}$ in the soil solution releases $\mathrm{H}^{+}$ions, resulting in the reduction of soil pH (Gomes et al., 2002).

A number of phenomena and factors may result in acidification of soils such as the acid rains with $\mathrm{H}^{+}$ions, the atmospheric deposition of sulfur dioxide $\left(\mathrm{SO}_{2}\right)$, ammonia $\left(\mathrm{NH}_{3}\right)$, nitric and hydrochloric acid $\left(\mathrm{HNO}_{3}\right.$ and $\left.\mathrm{HCl}\right)$, root exudation and organic matter mineralization (Goulding, 2016). These factors are prevalent in the soils of tropical regions (Caires et al., 2011).
Soils are evaluated by the activity of hydronium ions in the cation and anion exchange complex, which is measured by the $\mathrm{pH}$ value. Therefore, soils with $\mathrm{pH}$ in the water below 4.5 are considered acidic (Goulding, 2016).

In Brazil, one-third of the soils are classified as Oxisol (Typic Hapludox), and these soils are mainly characterized as acid soils (Santos, 2011). Therefore, these tropical soils have become effectively agricultural only due to the use of limestone (Caires et al., 2006). The main sources of limestone are calcite and dolomite extracted from sedimentary and metamorphic rocks (Rodrighero et al., 2015).

The quality of the limestone is measured by its reactivity, which uses its characteristic of particle size and $\mathrm{CaO}$ and $\mathrm{MgO}$ concentrations of the rock (Ratke et al., 2018). The lower particle size and higher oxide concentration usually causes higher limestone reactivity (Quaggio, 2000). Limestone may have a residual effect depends on its particle size, whereas the larger the particle size of limestone shows greater residual 
effect. Particles larger than $2.0 \mathrm{~mm}$ have low reactivity and should not be used (Quaggio et al., 1982). Due to the transportation cost of limestone, it is more economically feasible to use limestone sources of the region. Thus, in the state of Piauí, Brazil, the limestone used is extracted and produced in the Northeast region of Brazil, such as Piauí, Maranhão, and Ceará (Abracal, 2018).

The implantation of crops in an agricultural system in acid soils requires the efficient management of limestone (Caires et al., 2011). Thus, limestone has higher efficiency when applied and incorporated into the soil (Rodrighero et al., 2015). Therefore, before starting the no-till system (NTS), it is recommended that the incorporation of the limestone is carried out to a $0.30 \mathrm{~m}$ depth since the soil should not subsequently be stirred during the successive years of cultivation (Auler et al., 2017). In this way, soil structural degradation can be prevented, which favors soil conservation.

According to Fageria (2001), grain yield is the best characteristic to evaluate the use of fertilizer sources and soil acidity correctives. The evaluation of the fertilization efficiency or soil acidity correction can also be verified by the crop growth characteristics, but a control treatment without correction or fertilization should be used. This evaluation should be performed in production environments that cannot verify soil chemical characteristics or soil correction recommendations. The Cerrado region in the state of Piauí has no technical recommendations for the soil acidity correction. Therefore, this study was designed to evaluate the growth and productive characteristics of the soybean crop due to the use of regional limestones in the implantation of the no-till system in tropical soil.

\section{Results and Discussion}

\section{Morphophysiological variables at the beginning of flowering (R1)}

The morphological and productive characteristics of soybean were significantly affected using different limestone sources, except for the relative chlorophyll index (Table 2). Significant increases in the production components due to limestone application were also reported for the soybean by Miranda et al. (2005) and by Rodrighero et al. (2015) for the maize crop. The final plant stand was severely reduced by the absence of liming (Table 3). In the 2013/2014 season, the limestones with the highest concentration of $\mathrm{CaO}$ ( $\mathrm{C} 1$ and $\mathrm{C} 4)$ provided a larger plant stand. The low final plant stand in the control treatment is related to the presence of $\mathrm{Al}^{3+}$ and the low availability of nutrients in the soil, such as $\mathrm{Ca}^{2+}$, which resulted in lower root and shoot growth, leaving soybean plants less tolerant to drought stress. The $\mathrm{Ca}^{2+}$ is a constituent of cell wall pectates, and in soils with low $\mathrm{Ca}^{2+}$ availability. The cell wall structure can be modified by $\mathrm{Al}^{3+}$, preventing the protection of the plant cell and promoting its denaturation, causing thickening of the roots (Caires et al., 2008). The fine roots are the most efficient in the absorption of nutrients. Without these roots, the low plant nutrition results in the lower plant growth and grain yield (Ratke et al. 2014).

The relative chlorophyll index, independent of the agricultural year, was not influenced by limestone sources. Martins and
Pitelli (2000) showed that liming on soybean sowing has increased the content of chlorophyll $a$ and $b$ by $25.45 \%$ and $20.57 \%$, respectively. Nogueira et al. (2010) indicated that higher chlorophyll indices provided a higher photosynthetic rate, and consequently higher accumulation of dry matter in plants. The relative chlorophyll index is directly related to the dry matter and $\mathrm{N}$ levels in the soil, because when there is a larger leaf area, there is also greater shading between the leaves.

In both growing seasons, the sources of limestone C3, C4, C2 and $\mathrm{C} 1$ provided significant increases in leaf area index values of $152 \%, 138 \%, 147 \%$, and $128 \%$, respectively, when compared to the control treatment (Table 3). C1 limestone was efficient in increasing the leaf area index only in the 2013/2014 harvest. Martins and Pitelli (2000) found that application of liming increases the leaf area about $32.31 \%$ and shoot dry matter of $22.08 \%$, after 49 days of plant growth.

In turn, the higher leaf area index resulted in increased photosynthesis production. This increase of photoassimilates resulted in a greater translocation to the main drains of the plants, such as roots, pods, and grains. The grain yield of maize and soybean crops is directly linked to photosynthetic efficiency in the transformation of solar radiation intercepted and transformed into dry matter (Casaroli et al., 2007), which is highly dependent on the leaf area (Alcântara Neto et al., 2010). Regarding the photosynthetic components, there were significant effects for the photosynthetically active radiation (PAR) and the efficiency of the PAR. In the 2013/2014 growing season, all sources of limestone, except C1 limestone, were efficient in increasing the PAR, compared to the control treatment. In 2014/2015 harvest, only C3 limestone provided a significant increase in the efficiency of PAR, compared to the control treatment. The $\mathrm{C} 1$ and $\mathrm{C} 3$ limestones are the sources that have the highest $\mathrm{CaO}$ and lower $\mathrm{MgO}$ contents, respectively. The $\mathrm{Ca}^{2+}$ maintains the highest relative water content in soybean leaves, when they are submitted to drought stress (Fioreze et al., 2013).

The C4 and C2 limestone sources provided greater accumulation of shoot dry matter of the soybean plants, compared to the control treatment in the 2013/2014 growing season, as well as to the C3, C4 and C2 limestone sources during the 2014/2015 season (Table 3). The best results obtained from C3 source are related to the higher $\mathrm{Ca}^{2+}$ content in its composition (Table 1). Rodrighero et al. (2015) showed that the Ca content in soybean leaves was significantly higher with the use of calcitic limestone, and the $\mathrm{Mg}$ content in the soybean leaf tissue was significantly higher with the use of dolomitic limestone. However, no differences were observed among these limestones in soybean grain yield.

\section{Productive characteristics of soybean}

In the 2013/2014 growing season, the C3, C4 and C2 limestone sources promoted significant increases in the number of stems and number of pods per plant, compared to the control, while in the 2014/2015 harvest, only with the C4 and C1 limestone sources resulted in an increase in the number of pods (Table 4). The thousand-grain mass was significantly higher with the use of the C3 and C1 sources. However, grain yield was 
Table 1. Physicochemical characteristics of the different sources of limestone applied in the Oxisol of the Brazilian Cerrado.

\begin{tabular}{|c|c|c|c|c|c|c|c|c|c|}
\hline \multirow[t]{2}{*}{ Sources } & \multicolumn{3}{|c|}{$\begin{array}{l}\text { Percentage of particles retained in } \\
\text { sieves }{ }^{1}\end{array}$} & \multirow{2}{*}{$\begin{array}{l}\mathrm{RE} \\
(\%) \\
\end{array}$} & \multirow{2}{*}{$\begin{array}{r}\mathrm{CaO} \\
(\%) \\
\end{array}$} & \multirow{2}{*}{$\begin{array}{c}\mathrm{MgO} \\
(\%) \\
\end{array}$} & \multirow{2}{*}{$\begin{array}{l}\mathrm{PN} \\
(\%) \\
\end{array}$} & \multirow{2}{*}{$\frac{\text { RTNP }}{(\%)}$} & \multirow{2}{*}{$\begin{array}{l}\text { RATES } \\
\text { Mg ha }^{-1}\end{array}$} \\
\hline & 10 & 20 & 50 & & & & & & \\
\hline $\mathrm{C} 1$ & 0.00 & 9.40 & 23.00 & 83.28 & 47.93 & 2.52 & 91.56 & 76.26 & 3.24 \\
\hline C2 & 0.00 & 2.40 & 23.60 & 88.64 & 29.98 & 14.78 & 90.02 & 79.79 & 2.96 \\
\hline C3 & 1.60 & 15.20 & 29.20 & 74.56 & 46.04 & 1.01 & 84.45 & 62.97 & 4.03 \\
\hline C4 & 0.00 & 0.20 & 19.60 & 92.00 & 34.48 & 8.73 & 83.02 & 76.38 & 2.85 \\
\hline
\end{tabular}

${ }^{1}$ The standard sieve sizes are: $\mathrm{n}^{\circ} 10=2.00 \mathrm{~mm} ; \mathrm{n}^{\circ} 20=0.84 \mathrm{~mm}$, and $\mathrm{n}^{\circ} 50=0.297 \mathrm{~mm}$. RE: Power of reactivity; CaO: Calcium oxide; MgO: Magnesium oxide; PN: Power of neutralization; RTNP: Relative Total Neutralization Power; RATES: rates of limestone applied.

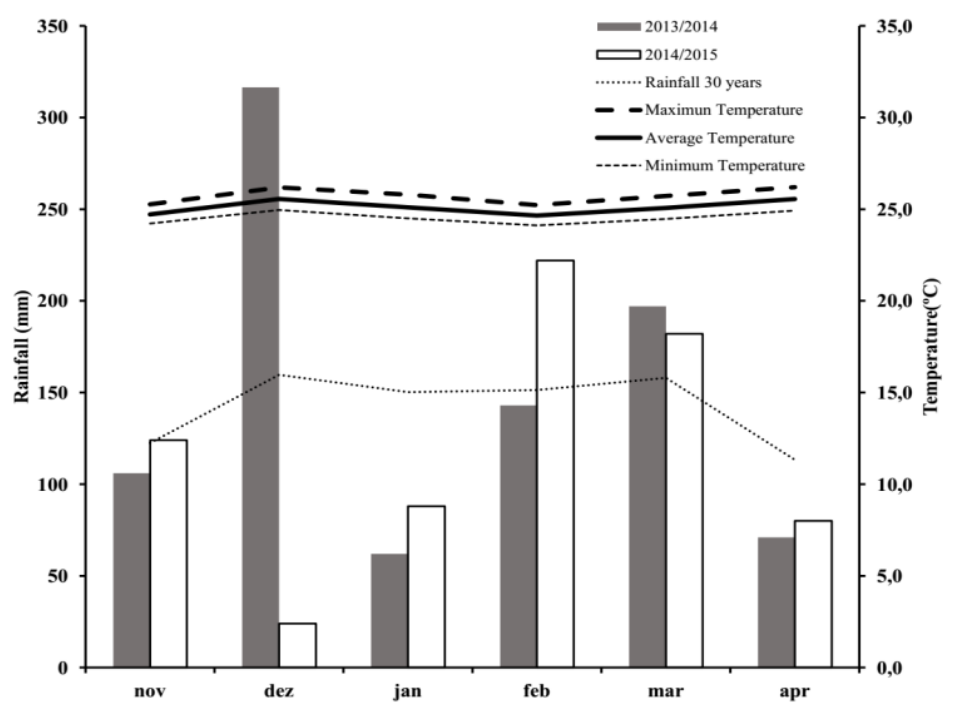

Fig 1. Monthly averages of rainfall and temperatures, occurring during the experiments at Fazenda Agropecuária Dois Irmãos, in Bom Jesus, Piauí, Brazil, during the 2013/2014 and 2014/2015 growing seasons.

Table 2. Summary of the analysis of variance for the fixed effects of the model with the structure variance and covariance of autoregressive errors for morphophysiological characteristics and grain yield of soybean crop grown in a tropical soil of the Brazilian Cerrado subjected to different limestone sources during the growing seasons of 2013/14 and 2014/15. Bom Jesus, State of Piauí, Brazil.

\begin{tabular}{|c|c|c|c|c|c|c|c|}
\hline \multirow{2}{*}{ Causes of variation } & \multirow{2}{*}{$\mathrm{DF}_{\mathrm{N}}{ }^{1}$} & \multirow{2}{*}{$\mathrm{DF}_{\mathrm{D}}^{2}$} & FPS & $\mathrm{RCl}$ & LAI & SDM & PAR \\
\hline & & & \multicolumn{5}{|c|}{ Probability $>\mathrm{F}$} \\
\hline Block & 3 & 12 & 0.0705 & 0.9339 & 0.2436 & 0.4485 & 0.1007 \\
\hline Limestone sources (LS) & 4 & 12 & $<0.0001$ & 0.2230 & $<0.0001$ & 0.0002 & 0.0075 \\
\hline Growing season (GS) & 1 & 15 & 0.0494 & $<0.0001$ & $<0.0001$ & $<0.0001$ & $<0.0001$ \\
\hline $\mathrm{LS} \times \mathrm{GS}$ & 4 & 15 & 0.0430 & 0.0584 & 0.0011 & 0.0166 & 0.0039 \\
\hline \multirow{2}{*}{ Causes of variation } & \multirow{2}{*}{$\mathrm{DF}_{\mathrm{N}}{ }^{1}$} & \multirow{2}{*}{$\mathrm{DF}_{\mathrm{D}}{ }^{2}$} & $\mathrm{PAR}_{\mathrm{E}}$ & NS & NPP & $1,000 \mathrm{M}$ & GY \\
\hline & & & \multicolumn{5}{|c|}{ Probability $>\mathrm{F}$} \\
\hline Block & 3 & 12 & 0.5337 & 0.2340 & 0.0611 & 0.2808 & 0.3763 \\
\hline Limestone sources (LS) & 4 & 12 & 0.0002 & $<0.0001$ & $<0.0001$ & $<0.0001$ & 0.0002 \\
\hline Growing season (GS) & 1 & 15 & $<0.0001$ & $<0.0001$ & $<0.0001$ & $<0.0001$ & 0.4950 \\
\hline $\mathrm{LS} \times \mathrm{GS}$ & 4 & 15 & $<0.0001$ & 0.0166 & 0.0295 & $<0.0001$ & 0.0260 \\
\hline
\end{tabular}

${ }^{1} \mathrm{DF}_{\mathrm{N}}$ : degrees of freedom of the numerator; ${ }^{2} \mathrm{DF}_{\mathrm{D}}$ : degrees of freedom of the denominator. Final plant stand (FPS), relative chlorophyll index (RCI), leaf area index (LAI), shoot dry matter (SDM), photosynthetically active radiation (PAR), photosynthetically active radiation efficiency (PARE), number of stems (NS), number of pods per plant (NPP), thousand grain mass $(1,000 \mathrm{M})$ and grain yield $(\mathrm{GY})$. 


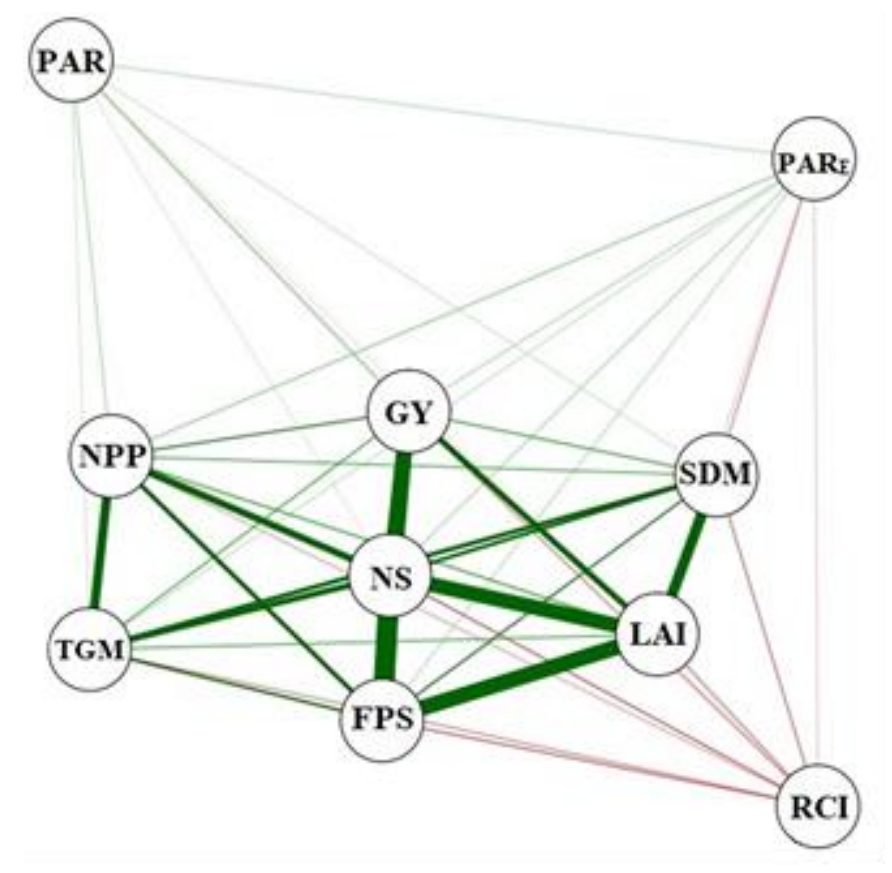

Fig 2. Pearson's correlation network $(P>0.60)$ of the morphophysiological characteristics of soybean: FPS - final plant stand; RCl relative chlorophyll index; LAI - leaf area index; SDM - shoot dry matter; PAR - photosynthetically active radiation, PAR photosynthetically active radiation efficiency; NS - number of stems; NPP - number of pods per plant; TGM - thousand grain mass; and GY - grain yield. The thickness of the lines was controlled by the estimation of the correlations, where the positive correlations were highlighted in the green color, while lines of red color represented the negative correlations.

Table 3. Final plant stand, Relative chlorophyll index, leaf area index, shoot dry matter, photosynthetically active radiation (PAR) and efficiency of photosynthetically active radiation of soybean crop grown in a tropical soil of the Brazilian Cerrado subjected to different limestone sources during the growing seasons of 2013/14 and 2014/15. Bom Jesus, State of Piauí, Brazil.

\begin{tabular}{|c|c|c|c|c|}
\hline \multirow{2}{*}{ Limestone sources } & \multicolumn{2}{|c|}{ Final plant stand (plant $\mathrm{m}^{-2}$ ) } & \multicolumn{2}{|c|}{ Relative chlorophyll index } \\
\hline & $2013 / 2014$ & $2014 / 2015$ & $2013 / 2014$ & $2014 / 2015$ \\
\hline Control & $11.37 \mathrm{cA}$ & $12.25 \mathrm{cA}$ & 49.88 & 54.74 \\
\hline $\mathrm{C} 1$ & $22.44 \mathrm{aA}$ & $22.00 \mathrm{aA}$ & 47.96 & 53.09 \\
\hline $\mathrm{C} 2$ & $19.81 \mathrm{bB}$ & $22.38 \mathrm{aA}$ & 48.03 & 52.89 \\
\hline C3 & $22.31 \mathrm{aA}$ & $21.25 \mathrm{aA}$ & 49.92 & 52.28 \\
\hline $\mathrm{C} 4$ & $19.69 \mathrm{bB}$ & $22.12 \mathrm{aA}$ & 46.88 & 53.94 \\
\hline \multirow{2}{*}{ Limestone sources } & \multicolumn{2}{|c|}{ Leaf area index } & \multicolumn{2}{|c|}{ Shoot dry matter $\left(\mathrm{g} \mathrm{m}^{-2}\right)$} \\
\hline & $2013 / 2014$ & $2014 / 2015$ & $2013 / 2014$ & $2014 / 2015$ \\
\hline Control & $10071.92 \mathrm{bA}$ & 4489.84 bB & $49.0 \mathrm{bA}$ & $26.05 \mathrm{cB}$ \\
\hline $\mathrm{C} 1$ & $25182.43 \mathrm{aA}$ & $8091.05 \mathrm{abB}$ & $59.0 \mathrm{abA}$ & $34.11 \mathrm{bcB}$ \\
\hline $\mathrm{C2}$ & $26586.55 \mathrm{aA}$ & $9366.05 \mathrm{aB}$ & $63.0 \mathrm{aA}$ & $38.18 \mathrm{bB}$ \\
\hline C3 & $26711.18 \mathrm{aA}$ & $9972.46 \mathrm{aB}$ & $57.5 \mathrm{abA}$ & $50.30 \mathrm{aA}$ \\
\hline C4 & $24631.34 \mathrm{aA}$ & $9983.79 a \mathrm{a}$ & $60.5 \mathrm{aA}$ & $38.53 \mathrm{bB}$ \\
\hline \multirow{2}{*}{ Limestone sources } & \multicolumn{2}{|c|}{$\operatorname{PAR}\left(\mathrm{mol} \mathrm{m}^{-2} \mathrm{day}^{-1}\right)$} & \multicolumn{2}{|c|}{ Efficiency of PAR } \\
\hline & $2013 / 2014$ & $2014 / 2015$ & $2013 / 2014$ & $2014 / 2015$ \\
\hline Control & $93.19 \mathrm{bA}$ & $89.69 \mathrm{abA}$ & $0.62 \mathrm{bA}$ & $0.52 \mathrm{bB}$ \\
\hline C1 & $117.73 \mathrm{abA}$ & $103.90 \mathrm{aA}$ & $0.82 \mathrm{aA}$ & $0.66 \mathrm{aB}$ \\
\hline $\mathrm{C} 2$ & $145.82 \mathrm{aA}$ & $71.65 \mathrm{bB}$ & $0.90 \mathrm{aA}$ & $0.52 \mathrm{bB}$ \\
\hline C3 & $137.33 \mathrm{aA}$ & $100.41 \mathrm{abB}$ & $0.91 \mathrm{aA}$ & $0.49 \mathrm{bB}$ \\
\hline C4 & $134.07 \mathrm{aA}$ & $100.69 \mathrm{abB}$ & $0.87 \mathrm{aA}$ & $0.51 \mathrm{bB}$ \\
\hline
\end{tabular}

Means represented by the different lowercase letters in the column and uppercase letters in the lines show significant differences (Tukey's test, $P \leq 0.05$ ). 
Table 4. Number of stems, number of pods per plant, thousand-grain mass and grain yield of soybean crop grown in a tropical soil of the Brazilian Cerrado subjected to different limestone sources during the growing seasons of 2013/14 and 2014/15. Bom Jesus, State of Piauí, Brazil.

\begin{tabular}{|c|c|c|c|c|}
\hline \multirow{2}{*}{ Limestone sources } & \multicolumn{2}{|c|}{ Number of stems per plant } & \multicolumn{2}{|c|}{ Number of pods per plant } \\
\hline & $2013 / 2014$ & $2014 / 2015$ & $2013 / 2014$ & $2014 / 2015$ \\
\hline Control & $6.25 \mathrm{cA}$ & $5.08 \mathrm{aB}$ & $27.58 \mathrm{cA}$ & $15.33 \mathrm{bB}$ \\
\hline $\mathrm{C} 1$ & $8.67 \mathrm{bA}$ & $6.41 \mathrm{aB}$ & $35.91 \mathrm{bcA}$ & $23.83 \mathrm{aB}$ \\
\hline $\mathrm{C} 2$ & $10.75 \mathrm{aA}$ & $6.50 \mathrm{aB}$ & $40.58 \mathrm{abA}$ & $20.58 \mathrm{abB}$ \\
\hline C3 & $10.00 \mathrm{abA}$ & $6.75 \mathrm{aB}$ & $44.25 \mathrm{abA}$ & $23.08 \mathrm{abB}$ \\
\hline C4 & $9.17 \mathrm{abA}$ & $6.42 \mathrm{aB}$ & $47.92 \mathrm{aA}$ & $24.17 \mathrm{aB}$ \\
\hline \multirow{2}{*}{ Limestone sources } & \multicolumn{2}{|c|}{ Thousand-grain mass (g) } & \multicolumn{2}{|c|}{ Grain yield $\left(\mathrm{kg} \mathrm{ha}^{-1}\right)$} \\
\hline & $2013 / 2014$ & $2014 / 2015$ & $2013 / 2014$ & $2014 / 2015$ \\
\hline Control & $59.5 \mathrm{bB}$ & $83.75 \mathrm{bA}$ & $895.0 \mathrm{bA}$ & $687.50 \mathrm{bB}$ \\
\hline C1 & $75.5 \mathrm{aB}$ & $197.50 \mathrm{aA}$ & $1187.5 \mathrm{aA}$ & $1306.25 \mathrm{aA}$ \\
\hline $\mathrm{C} 2$ & $71.5 \mathrm{abB}$ & $196.25 \mathrm{aA}$ & $1157.5 \mathrm{abA}$ & $1187.50 \mathrm{aA}$ \\
\hline C3 & $74.5 \mathrm{aB}$ & $191.25 \mathrm{aA}$ & $1150.0 \mathrm{abA}$ & $1232.50 \mathrm{aA}$ \\
\hline C4 & $72.0 \mathrm{abB}$ & $197.50 \mathrm{aA}$ & $1155.0 \mathrm{abA}$ & $1237.50 \mathrm{aA}$ \\
\hline
\end{tabular}

significantly higher only for the C1 source in the 2013/2014 harvest. Limestone sources provided satisfactory effects on the thousand-grain mass and the grain yield of soybeans in the 2014/2015 growing season, compared to the control. These results are like those reported by Miranda et al. (2005), which verified significant increases in soybean production components as a function of limestone application.

Rodrighero et al. (2015) reported that grain yield of maize and soybean crops in Oxisol and Entisols was increased with the limestone rates applied, but were not influenced by the sources and value of the relative total neutralization power (RTNP) of the correctives. Similar results were reported by Ratke et al. (2018), for maize yield with the use of dolomitic limestone with low RTNP in the first year of implantation of the no-till system.

The grain yield in the $2014 / 2015$ season due to the application of limestone is correlated to the morphological factors measured number of stems, thousand-grain mass, final plant stand, leaf area index, and number of pods (Figure 2). However, the photosynthetically active radiation and the relative chlorophyll index did not correlate with the grain yield of soybeans.

The morphological characteristics of the plant may not influence grain yield due to soybean having high phenotypic plasticity (Balbinot Junior et al., 2015). However, in this study, we verified that the morphological characteristics have high correlation with the grain yield of soybean cultivated with the application of different limestone sources. Thus, it cannot be generalized that the soybean crop presents high plasticity in different production environments.

The absence of the liming effect on the relative chlorophyll index may be related to the period of water restriction at the time of measurement, since chlorophyll content is not one of the reliable characteristics, when the plant is exposed to drought stress. According to Petter et al. (2013), the portable chlorophyll meters determine the relative and not absolute levels of chlorophyll. That is through the radiation transmitted in three light lengths through the chlorophyll molecule, when the relative chlorophyll index is estimated. According to these authors, the relative chlorophyll index is determined per unit area of the leaf. In the condition of moderate water restriction reduction in the turgescence (water potential) of the cells is occurred, which increases the number of cells and chloroplasts per unit area and consequently absorbance of light radiation.

\section{Materials and Methods}

\section{Description environments}

A field experiment was carried out in Bom Jesus, State of Piauí, Brazil, on as Oxisol or Typic Hapludox (Pragana et al., 2012), in the area of Cerrado native vegetation $\left(09^{\circ} 21^{\prime} 50^{\prime \prime} \mathrm{S}, 44^{\circ} 43^{\prime} 81^{\prime \prime}\right.$ $\mathrm{W}$, and altitude of $550 \mathrm{~m}$ ), during the 2013/2014 and 2014/2015 growing seasons. Before conducting these experiments, the residues of native vegetation were removed using a bulldozer, and then the field soil was plowed and harrowed to a depth of $0.25 \mathrm{~m}$ and divided into the plots before sowing. It should be noted that the area did not belong to a legal reserve or permanent reserve area according to the Brazilian forest code (Brasil, 2012).

The regional climate is Aw, according to the Köppen classification, which is characterized as tropical with hot summers and a tendency toward high rainfall levels, and dry winters, with a dry season between May and September (Peel et al., 2007). The mean annual temperature is $26.2{ }^{\circ} \mathrm{C}$, with a mean annual rainfall of $960 \mathrm{~mm}$. The rainfall and temperature data gathered during the experiments are shown in Figure 1.

Before starting the experiments, the soil was sampled the 0.0-0.20 m layer using a hole auger, and the results of the chemical analysis are as follows: $\mathrm{pH}\left(\mathrm{CaCl}_{2}\right)$ : 4.35; $\mathrm{P}$ (Mehlich1): $0.66 \mathrm{mg} \mathrm{dm}^{-3} ; \mathrm{K}^{+}: 10.77 \mathrm{mg} \mathrm{dm}{ }^{-3} ; \mathrm{Ca}^{2+}: 0.40 \mathrm{cmol}_{\mathrm{c}} \mathrm{dm}^{-3}$; $\mathrm{Mg}^{2+}: 0.10 \mathrm{cmol}_{\mathrm{c}} \mathrm{dm}^{-3} ; \mathrm{Al}^{2+}: 0.65 \mathrm{cmol}_{\mathrm{c}} \mathrm{dm}^{-3} ; \mathrm{H}+\mathrm{Al}: 4.9 \mathrm{cmol}_{\mathrm{c}}$ $\mathrm{dm}^{-3}$; base sum: $1.18 \mathrm{cmol}_{\mathrm{c}} \mathrm{dm}^{-3}$, cation-exchange capacity (CEC): $5.43 \mathrm{cmol}_{\mathrm{c}} \mathrm{dm}^{-3}$; soil base saturation (V\%): $9.76 \%$; $\mathrm{Al}^{3+}$ saturation (m\%): 56.31\%; clay: $167 \mathrm{~g} \mathrm{~kg}^{-1}$, silt: $17 \mathrm{~g} \mathrm{~kg}^{-1}$ and sand: $816 \mathrm{~g} \mathrm{~kg}^{-1}$. All chemical analyses were performed following the methodology described by Silva (2011).

\section{Design and trial management}

The experimental design was a randomized complete block design, and the treatments consisted of four limestone sources, 
including three sources of mining in state of Piauí $(\mathrm{C} 1, \mathrm{C2}$, and C3) and a mining source in state of Ceará (C4), plus a control treatment (without limestone), with four replicates, during two growing seasons (2013/2014 and 2014/2015). The limestone requirement was determined by the method of raising the base saturation as described by Sousa and Lobato (2004). The recommendation of the limestone need (i.e., $2.73 \mathrm{Mg} \mathrm{ha}^{-1}$ with Relative Total Neutralization Power of $100 \%$ ) was calculated aiming to raise the soil base saturation to $60 \%$. Then, the amount of limestone applied to each source of corrective was calculated according to its physicochemical characteristics, analyzed according to the methodology of Silva (2011) (Table 1).

The application of limestone was carried out in a single time, in the growing season of 2012/2013. After the application of the correctives, the soil was plowed and harrowed to a $0.20 \mathrm{~m}$ depth, in order to carry out the incorporation of the limestone into the soil. Afterward, the rice crop was cultivated in all experimental area. The implantation of the experiment with the soybean crop was carried out in the growing seasons of $2013 / 2014$ and 2014/2015, after the reaction of the limestone in the soil.

The soybean seeds (Monsoy 9350) were sown manually on December 02, 2013 (2013/2014 growing season) and December 06, 2014 (2014/2015 growing season), in rows of $0.50 \mathrm{~m}$ apart, at a density of 12 seeds $\mathrm{m}^{-1}$. Mineral fertilization was carried out by applying $350 \mathrm{~kg} \mathrm{ha}^{-1}$ of 02-30-20 formulation at sowing. The soybean seeds were previously inoculated with efficient Bradyrhizobium japonicum strains. The commercial liquid inoculant Nitragin Cell Tech $\mathrm{HC}^{\circ}$, containing SEMIA 5079 and SEMIA 5080 strains (minimum concentration of $3.0 \times 10^{9}$ viable cells per $\mathrm{mL}$ ) was used at a rate of $3.0 \mathrm{~mL} \mathrm{~kg}^{-1}$ of seeds. The management of weeds, pests, and diseases was carried out according to the requirements of the crop.

\section{Evaluations of soybean traits}

At the beginning bloom (R1 stage), the plant stand, relative chlorophyll index, photosynthetically active radiation, leaf area index and shoot dry matter was measured. These evaluations were performed at four random points of the experimental unit. The final plant stand was obtained by counting the total number of plants in a $2.0 \mathrm{~m}^{2}$ area. Relative chlorophyll index $(\mathrm{RCl})$ was measured using a portable chlorophyll meter (ClorofiLOG CSL1030), with five measurements at the third trifoliolate leaf totally expanded at all four random points of the plot.

The photosynthetically active radiation (PAR) was measured at midday $( \pm 12: 00 \mathrm{~h}$ ), aiming to reduce the interference of the zenith angle, using an AccuPAR PAR/LAI Ceptometer model LP80 (Decagon Devices, Inc., Pullman, WA, USA). Light intensity readings were performed above the plant canopy and at ground level. The apparatus was placed perpendicular to the soybean sowing row at an angle of $45^{\circ}$ to the zenith. The Ceptometer model LP-80 radiation data obtained in $\mu \mathrm{mol} \mathrm{m}^{-2}$ $\mathrm{s}^{-1}$ were then transformed into $\mathrm{mol} \mathrm{m}^{-2}$ day $^{-1}$, where $1.0 \mu \mathrm{mol}$ $\mathrm{m}^{-2} \mathrm{~s}^{-1}$ is equivalent to $0.0864 \mathrm{~mol} \mathrm{~m}^{-2} \mathrm{day}^{-1}$. The PAR data were recorded in $\mu \mathrm{mol} \mathrm{m} \mathrm{m}^{-2} \mathrm{~s}^{-1}$ and converted to $\mathrm{mol} \mathrm{m}^{-2} \mathrm{~s}^{-1}$ using Equation 1:

$\operatorname{PAR}=\sum_{\text {daily }} \operatorname{PAR}\left(\mu \mathrm{mol} \mathrm{m} \mathrm{m}^{-2} \mathrm{~s}^{-1}\right) \times \mathrm{t}(\mathrm{s})\left(\mathrm{mol}\right.$ of photons $\mathrm{m}^{-2}$ day $\left.^{-1}\right)$
Where PAR is the photosynthetically active radiation, $t$ is the time between the measurements, in seconds.

The intercepted photosynthetically active radiation (PAR) by the crop was calculated using Equation 2, as proposed by Varlet-Grancher et al. (1989):

$I P A R=P^{\prime} R_{i}-P R_{t}$

[2]

Where, IPAR is the interception of photosynthetically active radiation; $P A R_{i}$ is the photosynthetically active radiation incident; and, $\mathrm{PAR}_{\mathrm{t}}$ is the photosynthetically active radiation transmitted to the soil.

The interception efficiency $\left(\varepsilon_{\text {int }}\right)$ of PAR by soybean crop was estimated considering IPAR and $\mathrm{PAR}_{\mathrm{i}}$, according to Equation 3 : $\varepsilon_{\text {int }}=($ IPAR $/$ PARi $)$

\section{[3]}

After these measurements at the R1 stage, five plants of each one of the four random points of the plot were cut at the soil surface, collected into polythene bags, and transported to the laboratory. The leaves were then separated from the stem. The leaves were used to measure the leaf area index using a LI-COR Model LI-3000A Portable Area Meter. The leaves and stems

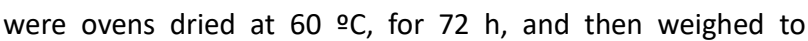
obtain the shoot dry matter production $\left(\mathrm{g} \mathrm{m}^{-2}\right)$.

At full maturity (R8 stage), grain yield and production components (number of stems, number of pods, and 1,000grain mass) were evaluated. Grain yield was determined at the end of the crop cycle, from a central portion of each plot of 2.0 $\times 1.0 \mathrm{~m}\left(2.0 \mathrm{~m}^{2}\right)$. Grains were cleaned and weighed, and the grain yield $\left(\mathrm{kg} \mathrm{ha}^{-1}\right)$ was estimated after the correction of grain weights to $13 \%$ of moisture. The number of stems per plant and number of pods per plant was determined in a random sample of three plants in the useful area of the plot, and the mass of 1,000 grains by the average of eight measurements of 100 grains taken at random (Brasil, 2009).

\section{Statistical analysis}

The data normality was previously tested by the Shapiro-Wilk test at the $5 \%$ significance level, and then the data were submitted to analysis of variance ( $F$ test, $p \leq 0.05$ ) of repeated measurements by adjusting the data to a mixed model and the means were compared by the Tukey test at the $5 \%$ probability level using the statistical software "R" version 3.5.0.

The morphological and productive characteristics of the soybean crop were analyzed by Pearson's correlation network with the aid of the RBio software (Bhering 2017).

\section{Conclusions}

Limestone is essential to improve plant growth and to increase grain yield of soybeans in acid soils. The use of limestone with lower Relative Total Neutralization Power (RTNP), such as C3 limestone, results in soybean grain yield equivalent to the use of limestone of higher RTNP. The lower agronomic efficiency in soybean grain yield is obtained with the use of C3 limestone due to its low power of reactivity and high $\mathrm{Ca} / \mathrm{Mg}$ ratio. The $\mathrm{C} 1$, $\mathrm{C} 3$ and C4 limestones have a low concentration of MgO. The use of limestone results in increased morphophysiological and productive characteristics of soybeans regardless of the source used. The grain yield of soybean crop grown in tropical soils with limestone application is correlated to leaf area index (LAI), 
thousand-grain mass (TGM), shoot dry matter (SDM), number of stems (NS) and pods per plant (NPP), and final plant stand (FPS).

\section{Acknowledgments}

This study was financed in part by the Coordenação de Aperfeiçoamento de Pessoal de Nível Superior - Brasil (CAPES) Finance Code 001, for granting of a scholarship to Adaniel Sousa dos Santos.

\section{References}

Abracal (2018) Calcário Agrícola. Retrieve in: http://www.abracal.com.br/estatisticas

Alcântara Neto F, Gravina GA, Souza NOS, Bezerra AAC (2010) Adubação fosfatada na cultura da soja na microrregião do Alto Médio Gurguéia. Rev Ci Agronômica. 41:266-271.

Auler AC, Pires LF, Caires EF (2017) Surface and incorporated liming effects on clay dispersion, water availability, and aeration capacity of a dystrudept soil. Bragantia. 76:433-446.

Balbinot_Junior AA, Procópio S de O, Debiasi H, Franchini JC, Panison F (2015) Semeadura cruzada em cultivares de soja com tipo de crescimento determinado. Semin Ciênc Agrár. 36:1215-1225.

Bhering LL (2017) Rbio: A tool for biometric and statistical analysis using the $\mathrm{R}$ platform. Crop Breed Appl Biotechnol. 17:187-190.

Brasil (2009) Regras para análise de sementes. Brasília: MMA.

Brasil (2012) LEI No 12.651, de 25 de maio de 2012 Dispõe sobre a proteção da vegetação nativa; altera as Leis $\mathrm{n}^{\circ} \mathrm{s}$ 6.938 , de 31 de agosto de 1981, 9.393, de 19 de dezembro de 1996, e 11.428, de 22 de dezembro de 2006; revoga as Lei $\mathrm{n}^{\circ} \mathrm{s}$ 4.771, de 15 de setembro de 1965. Retrieve in: http://www.planalto.gov.br/ccivil_03/_ato20112014/2012/lei/l12651.htm.

Caires EF, Barth G, Garbuio FJ (2006) Lime application in the establishment of a no-till system for grain crop production in Southern Brazil. Soil Till Res. 89: 3-12.

Caires EF, Barth G, Garbuio FJ, Churka S (2008) Soil acidity, liming and soybean performance under no-till. Sci Agric. 65:532-540.

Caires EF, Joris HAW, Churka S (2011) Long-term effects of lime and gypsum additions on no-till corn and soybean yield and soil chemical properties in southern Brazil. Soil Use Manage. 27:45-53.

Casaroli D, Fagan EB, Simon J, Medeiros SP, Manfron A, Dourado-Neto D, Lier QJV, Muller L, Martin TN (2007) Solar Radiation and Physiologics Aspects in Soybean - a Review. Rev FZVA. 14:102-120.

Fageria NK (2001) Efeito da calagem na produção de arroz, feijão, milho e soja em solo de cerrado. Pesqui Agropecu Bras. 36:1419-1424.

Fioreze SL, Rodrigues JD, Carneiro JPC, Do Amaral Silva A, Lima MB (2013) Fisiologia e produção da soja tratada com cinetina e cálcio sob deficit hídrico e sombreamento. Pesqui Agropecu Bras. 48:1432-1439.

Gomes FT, Borges AC, Neves Lima JC, Fontes PCR (2002) Influência de doses de calcário com diferentes relações cálcio:magnésio na produção de matéria seca e na composição mineral da alfafa. Pesqui Agropecu Bras. 37:1779-1786.
Goulding KWT (2016) Soil acidification and the importance of liming agricultural soils with particular reference to the United Kingdom. Soil Use Manage. 32:390-399.

Martins AP, Cecagno D, Borin JBM, Arnuti F, Lochmann SH, Anghinoni I, Bissani CA, Bayer C, Carvalho PCF (2016) Long-, medium- and short-term dynamics of soil acidity in an integrated crop-livestock system under different grazing intensities. Nutr Cycl Agroecosyst. 104:67-77.

Martins D, Pitelli RA (2000) Efeito da adubação fosfatada e da calagem nas relações de interferência entre plantas de soja e capim-marmelada. Planta Daninha. 18:331-347.

Miranda LN, Miranda JCC, Rein TA, Gomes AC (2005) Utilização de calcário em plantio direto e convencional de soja e milho em Latossolo Vermelho. Pesqui Agropecu Bras. 40:563-572.

Nogueira PDM, Sousa_Júnior DGS, Ragagnin VA (2010) Clorofila foliar e nodulação em soja adubada com nitrogênio em cobertura. Global Sci Tec. 3:117-124.

Peel MC, Finlayson BL, McMahon TA (2007) Updated world map of the Köppen-Geiger climate classification. Hydrol Earth Syst Sci. 11:1633-1644.

Petter FA, Pacheco LP, Zuffo AM, Piauilino AC, Xavier ZF, Moraes J, Marcos J, Miranda DS (2013) Performance of cover crop under the water deficit. Semin Ciênc Agrár. 34:3307-3320.

Pragana RB, Ribeiro MR, Nóbrega JCA, Filho MRR, da Costa JA (2012) Qualidade física de Latossolos Amarelos sob plantio direto na região do Cerrado Piauiens. Rev Bras Cienc Solo. 36:1591-1600.

Quaggio J (2000) A acidez e calagem em solos tropicais. Campinas: Instituto Agronômico de Campinas

Quaggio J, Mascarenhas HA, Bataglia O (1982) Resposta da soja à aplicação de doses crescente de calcário em Latossolo Roxo Distrófico de cerrado II- Efeito residual. Rev Bras Cienc Solo. 6:113-118.

Ratke RF, Pereira HS, Santos_Junior JDG, Barbosa JM, Lopes LO (2018) Different limestone particle sizes for soil acidity correction, $\mathrm{Ca}$ and $\mathrm{Mg}$ supply and corn yield. Comun Sci. 9:175-184.

Ratke RF, Pereira HS, Santos-Júnior JDGS, Frazão JJ, Barbosa JM, Dias BO (2014) Root Growth, Nutrition and Yield of Maize with Applied Different Limestone Particle Size in the Cerrado Soil. Am J Plant Sci. 5:463-472.

Rodrighero MB, Barth G, Caires EF (2015) Aplicação superficial de calcário com diferentes teores de magnésio e granulometrias em sistema plantio direto. $\mathrm{R}$ Rev Bras Cienc Solo. 39:1723-1736.

Santos HG (2011) O novo mapa de solos do Brasil: legenda atualizada. Rio de Janeiro: Embrapa Solos. Retrieve in: http://www.cnps.embrapa.br/solosbr/publicacao.html.

Silva FS (2011) Manual de análises de solos, plantas e fertilizantes. Brasíla: Embrapa.

Sousa DMG, Lobato E (2004) Cerrado: correção do solo e adubação. Brasíla: Embrapa Informação Tecnológica. 